\title{
KOMPLEXNÍ POHLED NA MIGRACI \\ Z PERA PROF. BORJASE
}

Dagmar Brožová, Vysoká škola ekonomická v Praze

George J. Borjas. Immigration Economics

Cambridge, MA; London, UK : Harvard University Press, 2014. 284 s.

ISBN 978-0-674-04977-2.

DOI: $10.18267 /$ j.polek.1020

Kniha G. J. Borjase, profesora ekonomie a sociální politiky na Harvard Kennedy School, je další z řady jeho excelentních publikací z oblasti ekonomie trhů práce. Syntetizuje teoretické poznání z oblasti ekonomie migrace, vysvětluje teorie a doprovází je přiměřeným algebraickým a srozumitelným grafickým aparátem. Pracuje s empirickými daty a představuje ekonometrické modely a metody vhodné $\mathrm{k}$ jejich zkoumání, zejména $\mathrm{k}$ identifikaci prríčin a důsledků mezinárodních migračních toků.

S ohledem na to, že asi 215 milionů lidí, což jsou přibližně $3 \%$ světové populace, nežijí v zemích, kde se narodili, stává se ekonomie migrace stále důležitější součástí nejen ekonomie trhů práce, ale celého ekonomického obrazu společnosti. Země rozvinutého světa se stávají „nations of imigrants“. I když prof. Borjas musel velmi zvažovat, kterým tématům věnuje prostor ve své nové knize, tématu migrace se dostalo uceleného zpracování vedeného jasnou logickou linkou neoklasické mikroekonomie, které je př́nosem pro intelektuální rozvoj teorie migrace. Efektivní alokaci pracovníků do pracovních míst a maximalizaci celkové hodnoty produktu zajišt'ují v konkurenční ekonomice trhy prostřednictvím vyrovnávání hodnoty mezního produktu práce. „Migrace je klíčovým nástrojem trhu práce $\mathrm{k}$ překonávání tržních neefektivností a k zajištění, že se pracovníci dostanou na taková pracovní místa, v nichž jsou nejproduktivnější, " píše prof. Borjas (s. 2). Představuje imigranty jako racionální ekonomické agenty, kteří činí ta nejlepší možná rozhodnutí s ohledem na zdroje, které mají k dispozici. Jejich chování má jednoznačné redistribuční konsekvence: jedni získávají a druzí ztrácejí.

Kniha je tematicky rozdělena do 9 kapitol a na konci je originální a obsahově inspirující závěr.

Kapitola 1 Výběr imigrantů (The Selection of Immigrants) popisuje migrační rozhodování. Borjas otevírá svoji ekonomii migrace jednoduchou otázkou: Kdo se rozhoduje migrovat? Již v roce 1932, laureát Nobelovy ceny John Hicks tvrdil, že jsou to rozdíly v čistých ekonomických výhodách, zejména pak rozdíly ve mzdách, které jsou hlavním důvodem migrace (The Theory of Wages. London, Macmillan, p. 76). Borjas vedle mzdového diferenciálu vysvětluje zásadní úlohu schopností: právě jejich distribuce odděluje (selection process) ty, kteří odcházejí ze země, od těch, kteří zůstávají. Diskutuje i další faktory, které motivují některé osoby z původních zemí emigrovat. Borjas přináší ekonomický model migračního rozhodování jakožto rozhodování o investici do lidského kapitálu. Lidé, kteří se rozhodnou migrovat, předpokládají, že jejich očekávané výnosy z migrace převýší náklady na ní. Teoretické vysvětlení ilustruje aplikace grafického Royova modelu (Roy, A. D., 1951, 
Some Thoughts on the Distribution of Earnings. Oxford Economic Papers, 3, June 1951, pp. 135-46.) Vůbec první aplikaci Royova modelu na migraci provedl právě prof. Borjas (in Self-Selection and the Earnings of Immigrants v American Economic Review, 77, September 1987, pp. 531-53). V základní a rozšířených verzích odlišuje pozitivní a negativní migrační toky. Imigranti následně potřebují získat v nové zemi i nové schopnosti. Právě tyto následné investice (post-migration investment) pak určují míru ekonomické integrace imigrantů a domácí populace v přijímající zemi. Závěr kapitoly tvoří empirický test Royova modelu (cross-country regression model) a diskuse vybraných empirických studií analyzujících migrační toky v konkrétních zemích.

J. Mincer (Family Migration Decisions. Journal of Political Economy, 86, October 1978, pp. 749-73) na rozdíl od této individuální volby poukazuje na to, že velká část migračního rozhodování se týká nikoli jednotlivců samotných, ale celých rodin. Potom jde o to, za jakých podmínek na tom bude celá rodina lépe, a tudíž migrační rozhodování nemusí nutně přinášet pozitivní výnos pro všechny členy rodiny. S. H. Sandell (Women and the Economics of Family Migration. Review of Economics and Statistics, 59, November 1977, pp. 406-14) poukazuje na statistická data, která potvrzují, že např. postmigrační výdělky žen jsou často nižší než před migrací.

Kapitola 2 Ekonomická integrace (ECOnomic Assimilation) ukazuje, že ne všechny schopnosti jsou transferabilní z jedné země do druhé. Migranti obvykle pocit’ují nedostatek určitých schopností, které jsou pro trh práce žádoucí (jako je např. plynulá znalost jazyka). Mají proto motiv pokračovat $\mathrm{v}$ investičním procesu do svého lidského kapitálu a získat takové schopnosti, které by mohli zužitkovat v novém prostředí. V této kapitole autor odvozuje a testuje model ekonomické integrace migrantů a determinanty, které ji ovlivňují. Podává rovněž přehled ekonometrických metod, které se využívají k měření míry této integrace. Diskuse zdůrazňuje složitost oddělení míry ekonomické integrace od změn původních schopností imigrantů. Kombinace pre- a postmigračních schopností pak určuje aktuální nabídku schopností imigrantů zaměstnavatelům v přijímající zemi.

Kapitola 3 Imigrace a struktura mezd: teorie (Immigration and the Wage Strukture: Theory) zkoumá vliv imigrace na mzdy. Teoretický model konkurenčního trhu práce dává jasnou odpověd', jak zareaguje mzda na př́ichod imigrantů: s velkým počtem migrantů se bude snižovat relativní mzda těch pracovníků, kteří jsou k migrantům konkurenty, tedy pokud jsou migranti a domácí pracovníci vzájemně substituovatelní; a zvyšovat mzda těch, kteří jsou s nimi v komplementárním vztahu, a to zejména v krátkém období.

Borjas si v této kapitole klade otázku, jak může přispět teorie poptávky $\mathrm{k}$ vyjasnění potenciálního mzdového efektu posunu nabídky práce $\mathrm{v}$ důsledku migrace. Ústřední úvaha vychází ze skutečnosti, že příchod imigrantů zároveň zvyšuje poptávku po zboží a tím vytvárí prostor pro růst mezd: „Jak moc zvyšují imigranti spotřebitelskou základnu přijímající země? ... Odpověd' na tuto otázku, které se zatím nedostalo empirického zkoumání, hraje ústřední roli $\mathrm{v}$ determinaci vlivu imigrace na mzdy, a to jak v krátkém, tak v dlouhém období“ (s. 78).

Kapitola 4 Mzdové efekty imigrace: deskriptivní důkazy (The Wage Effects of Immigration: Descriptive Evidence) sumarizuje empirickou literaturu, která se zabývá vlivem mezinárodní migrace na pracovní př́ležitosti na strukturu mezd $\mathrm{v}$ prijímajících a vysílajících zemích. Poukazuje na skutečnost, že empirická literatura zaměřuje svoji pozornost na přijímající země, ale pomíjí ty vysílající. Diskutuje deskriptivní metody, které korelují mzdu určitých skupin pracovníků se změnami nabídky práce těchto skupin.

Kapitola 5 Mzdové efekty imigrace: strukturální odhady (The Wage Effects of Immigration: Structural Estimates) diskutuje strukturální 
modely, které odhadují všeobecnou rovnováhu trhu práce a zahrnují parametr reprezentující vliv imigrace na strukturu mezd.

Empirická literatura sumarizovaná v těchto kapitolách nabízí pro každého něco: Některá empirická zkoumání vedou k závěrům, že imigrace nemá vliv na mzdu konkurenčních domácích pracovníků, jiné modely prokazují, že imigrace má negativní, event. pozitivní vliv na mzdy konkurenčních domácích pracovníků. Borjas uzavírá, že se ukázalo překvapivě složitým empiricky demonstrovat triviální teoretickou implikaci, že zvýšení nabídky práce snižuje mzdu.

Kapitola 6 Přizpůsobení trhu práce imigraci (Labor Market Adjustments to Immigration) se zaměřuje na analýzu chování domácích pracovníků a firem v reakci na imigranty. Jestliže má imigrace vliv na pracovní př́ležitosti a mzdy v přijímající zemi, původní účastníci trhu práce, at' již pracovníci nebo firmy, čelí měnícím se podmínkám. Kapitola vysvětluje determinanty a konsekvence dvou typů přizpůsobení. Domácí pracovníci mohou reagovat na imigraci odchodem (nebo naopak setrváním) do dalších měst a lokalit, kterým se imigranti vyhýbají. Podobně firmy mohou např. na rostoucí počet nízko kvalifikovaných imigrantů reagovat změnou mixu svých kapitálových investic.

Kapitola 7 Ekonomické př́nosy migrace (The Economic Benefits from Immigration) představuje teoretický rámec $\mathrm{k}$ vysvětlení, jak a proč benefitují přijímající země z migrace. Prezentuje základní model, který popisuje zdroje výnosu z migrace, a aplikuje ho na kontext USA. Důležitým zjištěním je, že některé parametry, které determinují redistribuční vliv migrace na strukturu mezd, také determinují míru čistého ekonomického výnosu, který připadne přijímající ekonomice: čím větší je ztráta na mzdách domácích pracovníků, tím vyšší je čistý výnos z migrace v cílové zemi. Následuje ekonomický a grafický model imigračního prrebytku (immigration surplus) v krátkém a dlouhém období.

Kapitola 8 Vysoce kvalifikovaná imigrace (High-Skill Immigration) dále tento základní model aplikuje na globální kontext, kde nejsou migraci kladeny žádné překážky.

Základní model konkurenčního trhu práce predikuje, že čistý ekonomický výnos z imigrace je pro přijímající zemi relativně malý. Prof. Borjas uvádí, že v kontextu USA, pokud nabídkový šok zvýší počet pracovníků o $15 \%$, vygeneruje čistý výnos kolem $0,3 \%$ HDP v krátkém období; v dlouhém období je tento výnos ještě nižší (s. 170). Mnoho studií zdůrazňuje, že výnosy by mohly být větší, pokud by imigrační tok sestával z vysoce kvalifikovaných pracovníků. Kapitál a vysoce kvalifikovaná práce jsou v komplementárním vztahu (capital-skill complementarity hypothesis) a zvyšují produktivitu i výnos z migrace. Vysoce kvalifikovaní imigranti přinášejí pozitivní externalitu na produktivitu ostatních pracovníků v cílové zemi. Kapitola prezentuje modely těchto pozitivních externích efektů a sumarizuje empirické modely, které měří pozitivní externality na lidský kapitál.

Kapitola 9 Druhá generace (The Second Generation) zkoumá skladbu schopností dětí imigrantů a faktory, které determinují dlouhodobý vliv imigrace na ekonomiku přijímající země. Vliv imigrace na ekonomiku přijímající země závisí nejen na chování a rozhodování první generace imigrantů, ale také na míře integrace druhé generace. Potvrzuje silnou korelaci mezi většinovými schopnostmi různých národnostních skupin imigrantů a schopnostmi korespondující etnické skupiny druhé generace imigrantů. K vysvětlení této korelace některé studie uvádějí, že děti ze skupin, které mají výhodnější „etnický kapitál“", jsou úspěšnější na trhu práce než ty ze znevýhodněných etnických skupin.

Kapitola sumarizuje jak teoretický rámec, tak empirické př́stupy, které zkoumají povahu a determinují empirickou relevanci etnické externality (ethnic externality).

Prof. Borjas v závěru své knihy namísto obvyklého shrnutí základních poznatků a zjištění nabízí několik závěrečných úvah směřujících $\mathrm{k}$ formulací otevřených otázek, které 
zůstávají v této oblasti dosud neřešeny a nevyřešeny. Ačkoliv literatura o migraci v posledních třech dekádách výrazně pokročila, a to zejména $v$ oblasti ekonometrických metod a modelů, které představují solidní základ pro budoucí výzkumy, ekonomie migrace nadále zůstává intelektuální výzvou.

První se týká základní otázky: Jak identifikovat ty, kteří se rozhodnou pro migraci? Za klíčový problém pro existující modely označuje prof. Borjas skutečnost, že zůstávají u předpokladu, že imigranti reagují na mzdový diferenciál mezi zeměmi. Na základě něj se pak rozdělují mezi „movers a stayers“. Tento předpoklad se ukazuje být adekvátní, pokud imigranti tvoří jen malou část populace $\mathrm{v}$ dané zemi. ,... př́stup dílčí rovnováhy však jednoduše propadá, jestliže imigrace začíná mít významný vliv na strukturu mezd v různých zemích“ (s. 212). Když migrační toky výrazně posílí a začnou mít vliv na strukturu mezd, jak v přjímajících tak ve vysílajících zemích, pak dojde $\mathrm{k}$ četným následným změnám na souvisejících trzích a v aktuálním ekonomickém výzkumu chybí poznání povahy těchto širších souvislostí a tudíž výběru imigrantů v kontextu všeobecné rovnováhy trhů.

Druhou oblastí, na kterou prof. Borjas poukazuje, je ekonomická integrace imigrantů $\mathrm{v}$ prrijímající zemi. Míra integrace závisí na jejích ekonomických př́nosech $\mathrm{z}$ přizpůsobení domácí populaci, které jdou do rukou imigrantů. Jde o postimigrační investice, které imigranti budou ochotni uskutečnit, pouze když z nich budou profitovat. Proto je třeba porozumět faktorům, které mohou zpomalovat nebo urychlovat míru ekonomické integrace v první generaci imigrantů. To vyžaduje identifikaci faktorů, na kterých závisí relativní mzdy imigrantů v průběhu času.

$\mathrm{S}$ tím souvisí i vliv imigrace na mzdy. Tady vidí prof. Borjas kruciální problém v tom, že stejná data zkoumaná různými ekonometrickými postupy vedou $\mathrm{k}$ různým výsledkům. Bylo by prospěšné identifikovat metody, které jsou schopné poskytovat ty nejlepší odhady mzdových efektů imigračních procesů. Velmi málo úsilí bylo také věnováno zkoumání ekonomických vlivů mezinárodní migrace ve vysílajících zemích. Odliv pracovníků, často vysoce kvalifikovaných, mění mzdovou strukturu a skladbu lidského kapitálu, a to může mít významné ekonomické a sociální implikace.

Imigrace mění ekonomické př́ležitosti pro různé subjekty a ty potom mají motivaci reagovat a přizpůsobit se. Literatura orientuje svoji pozornost na výzkum pohybu domácích pracovníků po vlastní zemi poté, co imigranti obsadili určité lokality a určitá pracovní místa. Tím ale procesy prrizpůsobení nejsou zdaleka vyčerpány. Jde také o realokaci firem, změny struktury výroby, změny struktury firemního kapitálu, změny lidského kapitálu u určitých segmentů domácích pracovníků, aby se vyhnuli konkurenci na trhu práce. Tato přizpůsobení mají své náklady, a to u pracovníků i firem, v přijímajících i vysílajících zemích.

Toto úzce souvisí s výnosy a benefity $\mathrm{z}$ migrace $\mathrm{v}$ přijímajících zemích. Základní model konkurenčního trhu práce vede k závěru, že čistý výnos z migrace je kladný. Přestože ekonometrické modely jsou zde standardním a užitečným nástrojem, chybí důkaz o tom, že skutečné výnosy z migrace jsou opravdu kladné. Řada studií hledá externí efekty, které mohou přinést vysoce kvalifikovaní imigranti na domácí pracovní sílu. Tato se ale přizpůsobuje šokům ze strany nabídky práce a tato přizpůsobení mohou být velmi nákladná, a to vyvolává nedostatečně prozkoumanou otázku týkající se blahobytu: za jakých podmínek na tom bude domácí populace po přizpůsobovacích procesech lépe než před příchodem imigrantů? A bývají tyto podmínky skutečně splněny (viz s. 214)? Dosud málo prostoru bylo rovněž věnováno zkoumání vlivu imigrace na zisky firem.

Existující výzkum rovněž pokládá migrační politiky za exogenní okolnosti. Pak zkoumá, jak ovlivňují velikost, načasování a složení imigračních toků jakožto odezvu na stanovenou politiku. Bylo by však potřebné 
zkoumat, jak ekonomie artikuluje pro danou zemi optimální migrační toky a generuje optimální imigrační politiku. A zda má opravdu zamýšlené a žádoucí důsledky týkající se množství a skladby migrujících. Ještě méně je známo, jak endogenita imigrační politiky ovlivňuje náklady a výnosy v přijímající zemi. Protože je vliv imigrace dlouhodobý, zajímavou souvislostí, která se nabízí k výzkumu, je, jak mohou etnické efekty urychlit nebo zpozdit ekonomický vzestup druhé generace imigranti̊.

Je nepochybné, že kniha prof. Borjase je velkým př́nosem k rozvoji poznání ekonomie migrace, a to nejenom ucelenou teorií a provedenými empirickými výzkumy. Zároveň přináší mnoho podnětných myšlenek pro další zkoumání, pojmenovává nová témata a formuluje otázky, které na svoje odpovědi teprve čekají. Vysoce profesionální př́istup poskytne inspiraci nejen odborníkům, kteří se problematikou ekonomie migrace zabývají; aktuální pohled a moderní zpracování nepochybně zaujme i studenty, kteří si v ní najdou nové výzvy. Tak, jak prof. Borjas píše, že v ekonomii migrace je stále co zkoumat, s potěšením se chce dodat, že v jeho knihách je stále co číst. 